\title{
ASSESSMENT OF KARSTIFICATION DEGREE IN THE COPACABANA GROUP FOR A TAILINGS DAM FOUNDATION, SOUTH ANDES, PERU
}

\author{
Valeria Ramirez \\ Knight Piésold Consultores S.A., Calle Aricota 106, Dpto. 501, Santiago de Surco, Lima, Lima 33, Perú, \\ vramirez@knightpiesold.com
}

\section{Olimpio Angeles}

Knight Piésold Consultores S.A., Calle Aricota 106, Dpto. 501, Santiago de Surco, Lima, Lima 33, Perú oangeles@knightpiesold.com

Michael W. West

Wiss, Janney, Elstner Associates, Inc., 3609 S. Wadsworth, Suite 400,Lakewood, CO 80235, USA, mwest@wje.com

\begin{abstract}
The worldwide occurrence of carbonate rocks is extensive, and Peru is no exception. Many mining facilities are located in or on carbonate rocks. Under specific conditions, carbonate rocks show varying degrees of karstification, which represent a potential high risk of damage or failure to mine facilities, especially tailings and water impoundments due to subsidence or internal erosion problems. Adequate engineering measures, including proper characterization of the foundation materials, should be taken to characterize foundation materials and mitigate the risk.
\end{abstract}

This paper presents the assessment of the potential of karst dissolution in the Copacabana Group underlying about $50 \%$ the foundation of a proposed tailings dam and storage facility, located in the South Andes of Peru. A thorough geotechnical site investigation program was carried out in the area, which included regional and local geological mapping, geotechnical drilling, test pits, permeability tests, effervescence test in cores, petrographic analyses, and X-Ray diffraction tests. Hydrogeological studies, such as pumping and tracer tests, were also performed by other consultants to verify the observations, conclusions, and opinions developed from the geotechnical investigation program.

The results of the geotechnical investigation allowed proper characterization of the dam foundation and the tailings storage facility and estimation of the degree of karstification in the carbonate rocks of the Copacabana Group. The completed geological site characterization was then used to locate the tailings dam and impoundment area to avoid areas of pervasive karst and to implement defensive engineering measures, including grout curtains and slush grouting of smaller cavities and joints, among others.

\section{Introduction}

The tailings storage facility (TSF) is located in the South Andes of Peru, at -14.27 latitude, -70.31 longitude and an altitude between 4200 and 4500 m.a.s.l (Figure 1). Approximately, $50 \%$ of the foundation is underlain by the Copacabana Group, which is predominantly limestone. The remainder of the TSF foundation is underlain by the Ambo Group which is a clastic sequence (sandstone, siltstone, and shale).

This paper presents the assessment of the karstification degree of the Copacabana Group, based on information from geologic and geotechnical investigations, laboratory test results, and bibliographic research. This information allowed us to define the best location of the tailings dam (total height of $80 \mathrm{~m}$ ), the axis of which is oriented in a $\mathrm{N}-\mathrm{S}$ direction, and to determine the engineering measures necessary to mitigate the risks to the TSF.

\section{Conditional Factors for the Development of Karstification}

Limestones and dolostones constitute the rocks prone to dissolution activity at the project site. In order for a sequence of rocks to develop karstification, it is necessary for certain factors to act together. The most important factors are given below (Waltham, Bell \& Culshaw, 2010). 


\section{Mineral Composition}

Calcite $\left(\mathrm{CaCO}_{3}\right)$ is the principal component of limestones and is soluble in carbonic acid $\left(\mathrm{H}_{2} \mathrm{CO}_{3}\right)$, present in natural waters. Another important component of carbonate rocks is dolomite $((\mathrm{Ca}$, $\left.\mathrm{Mg})\left(\mathrm{CO}_{3}\right)_{2}\right)$, which is the principal component of dolostones, and presents a slower dissolution rate in comparison to the calcite.

\section{Organic Material Content and Water pH}

The dissolution potential of water with respect to calcite $\left(\mathrm{CaCO}_{3}\right)$ is related to the $\mathrm{CO}_{2}$ content of the soil, which originates mostly due to the decomposition of organic material and dissolution in rain water as it infiltrates through the soil. Also, the humic acids in the soil can produce underground waters with $\mathrm{pH}$ values ranging between 4.5 and 5 and in some extreme cases, values lower than 4 , which intensify the karstification process.

\section{Hydraulic Conductivity}

The hydraulic conductivity of the limestones depends on its lithology and structural orientation. These geologic controls also affect the karstification degree because they facilitate or interrupt the penetration of the surface waters. The hydraulic conductivity depends, to a large degree, on the joints and discontinuities created during diagenesis and the subsequent deformation of the bedding.

\section{Physiographic Location and Weather}

The development of karstification also depends on the location of the study area, as well as the weather of the area. Karst is common in tropical regions (terrains at lower altitudes) with high humidity and temperature, which produces more $\mathrm{CO}_{2}$ in the soil (more biologic activity) and higher precipitations.

\section{Human Activity}

The dissolution can be accelerated due to the changes in underground waters induced by human activity, or because of changes in the quantity, geochemistry, distribution, and flow of the surface waters that drain through the limestones.

\section{Geological-Geotechnical Investigation}

The geological-geotechnical investigations were executed in order to evaluate the foundation of the future TSF, the characteristics of the geological structures (faults and folds) and the degree of karst dissolution present in the study area, through the execution of in situ and laboratory tests.

The investigations consisted of: geological mapping (local and regional), execution of geotechnical boreholes (vertical and oriented), permeability tests, test pits and trenches, and the installation of piezometers (Figure 1). Also, hydrogeological studies and tests by other consultants were performed, in order to support

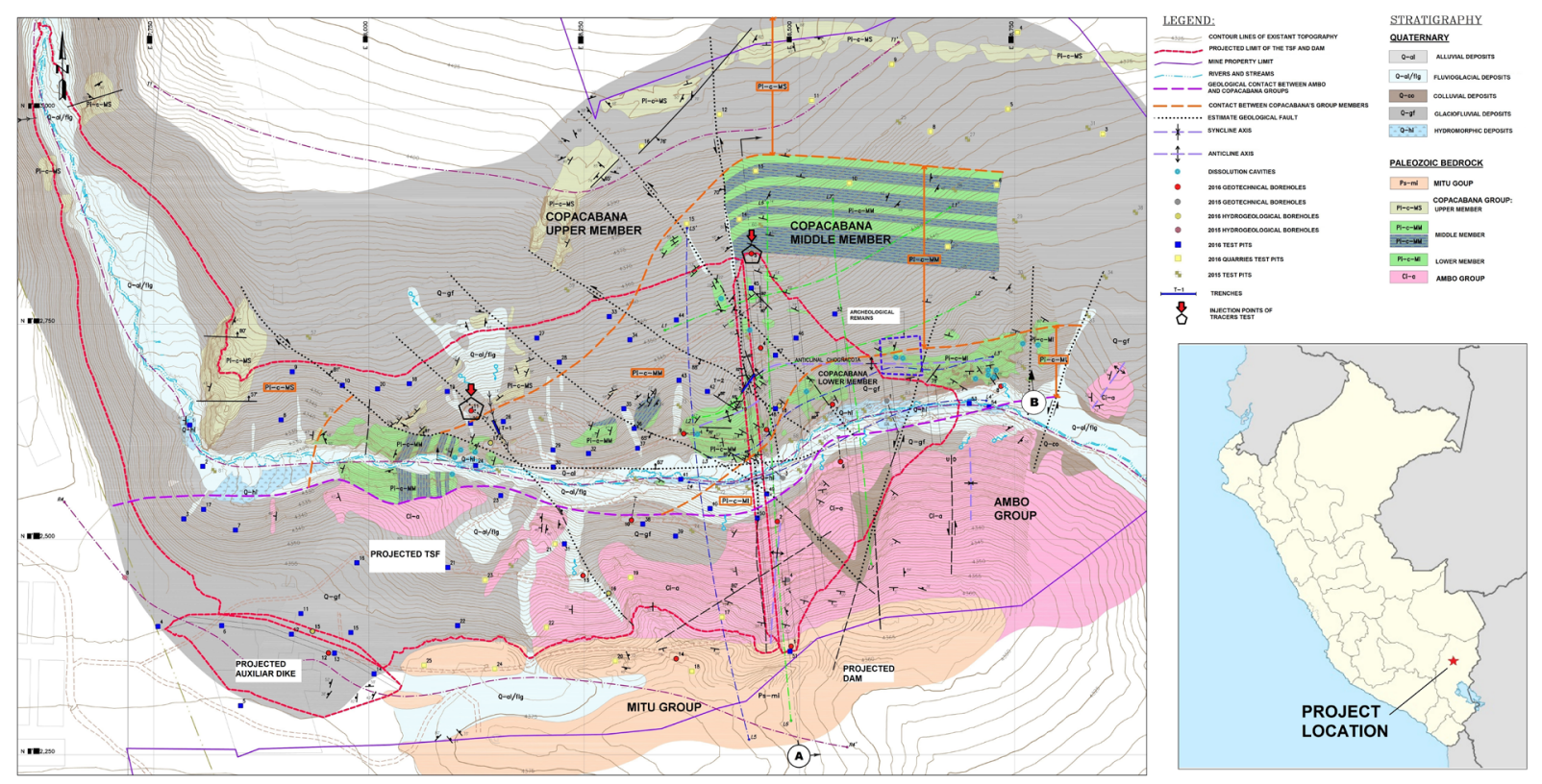

Figure 1. Map of Peru with geographic location of the project (right) and geological map with location of geotechnical investigations (left). 
and verify the results of the geological-geotechnical investigations.

In earlier stages of the project, geophysical tests (geoelectric tomography, seismic refraction, and MASW) were conducted with the purpose of determining the stratigraphic characteristics and competence of the bedrock at the TSF site and to detect cavities and fault zones. The results provided a preliminary idea of foundation conditions in the area.

\section{Geological Mapping}

With the objectives of defining lithological units, important geological structures, and evidence of karst dissolution in the study area, geological mapping was conducted by examining outcrops register, road access cuts, and borehole platforms.

\section{Geological Units}

Based on the regional geology (Lopez et al., 1996) and local geological mapping, the TSF site is underlain, in ascending stratigraphic order, by the Ambo Group siltstones and sandstones (Lower Carboniferous), the Copacabana Group limestones (Lower Permian), and the Mitu Group sandstones and conglomerate (Upper Permian). The Paleozoic bedrock is mostly covered by Quaternary deposits (glacial, glacial-fluvial, and alluvial). All these geological units are presented in Figure 2, which shows the stratigraphic column of the project.

The calcareous rocks of the Copacabana Group are exposed on the north valley slope; the Ambo Group, which underlies the Mitu Group by angular discontinuity, is exposed on the south valley slope. Figures 3 and 4 present cross sections along the dam axis and along the river axis, respectively.

Because of the importance of the Copacabana Group to the project, a more detailed description of its stratigraphic characteristics is presented in a following section of this paper.

\section{Structural Geology}

Unconsolidated surficial deposits mantle the bedrock and mask structure through much of the project area, especially along the valley floor; however, we consider that the most important structural features present in the area correspond to block faulting, related folding, and angular discordance between bedrock units (Figure 1).

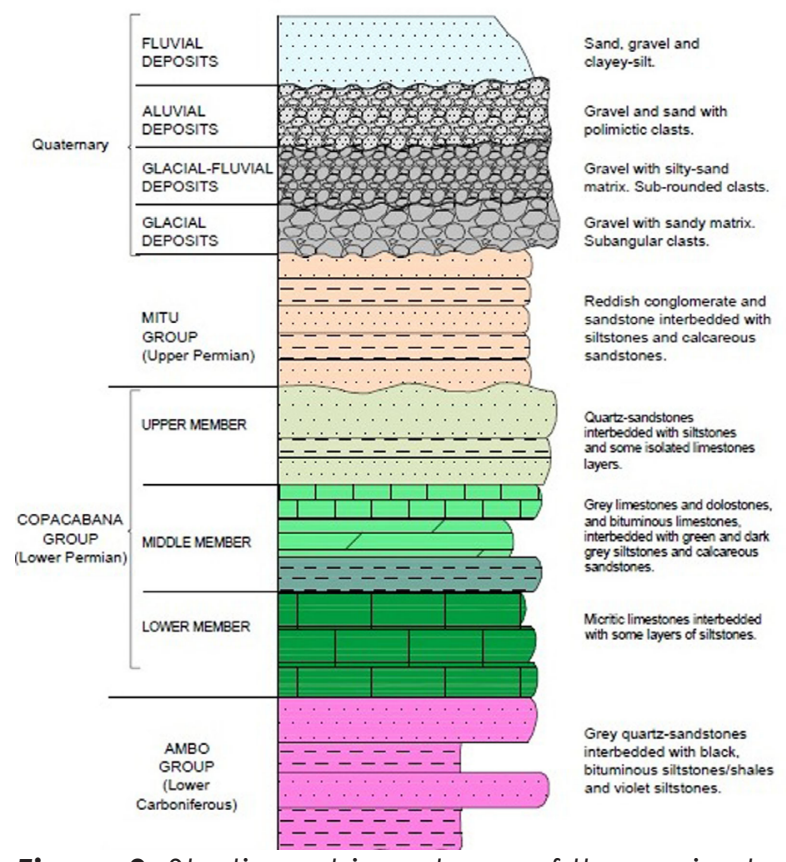

Figure 2. Stratigraphic column of the project.

The arrangement of these structures has direct influence over the quality of the rock mass and the flow direction and confinement of the underground water.

A major east-west-striking fault system, comprising two separate fault strands, is inferred to underlie the dam site and the impoundment area in the east-west section of the valley. The fault system juxtaposes Ambo Group sandstones on the south side of the valley against lower and middle units of the Copacabana Group along the north side of the valley. This fault likely accounts for the abrupt, rectilinear change in the valley from northnortheast to east-west.

A second group of faults strikes northwesterly to almost due north generally on the north side of the valley. These faults displace Copacabana units and may displace the east-west fault system controlling the drainage through the dam site area. Other minor faults and folds are present in the Ambo Group on the south side of the valley and elsewhere in the general project area.

The fault system underlying the valley floor and the northwest to north-striking faults cutting the Copacabana Group on the north valley slope faults likely provide some control of karstification near the dam site and may separate an area of relatively severe karstification downstream of the dam site from less severe solution activity in the impoundment area. 


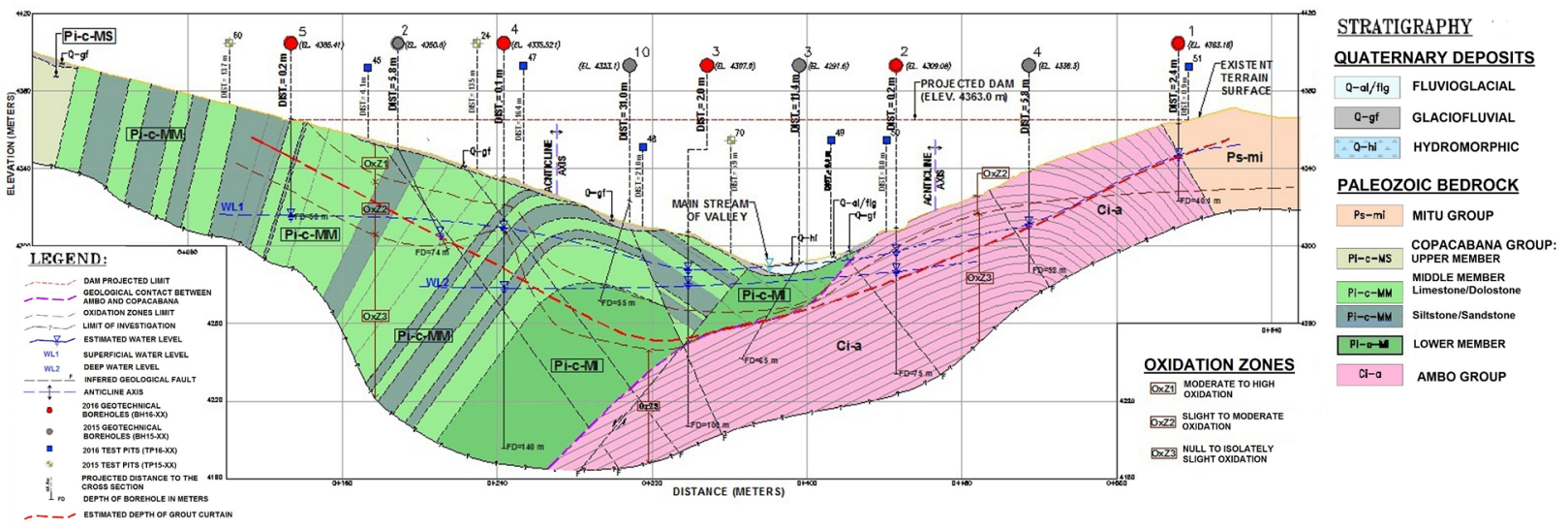

Figure 3. Geological cross section A-A' along the dam axis (looking downstream).

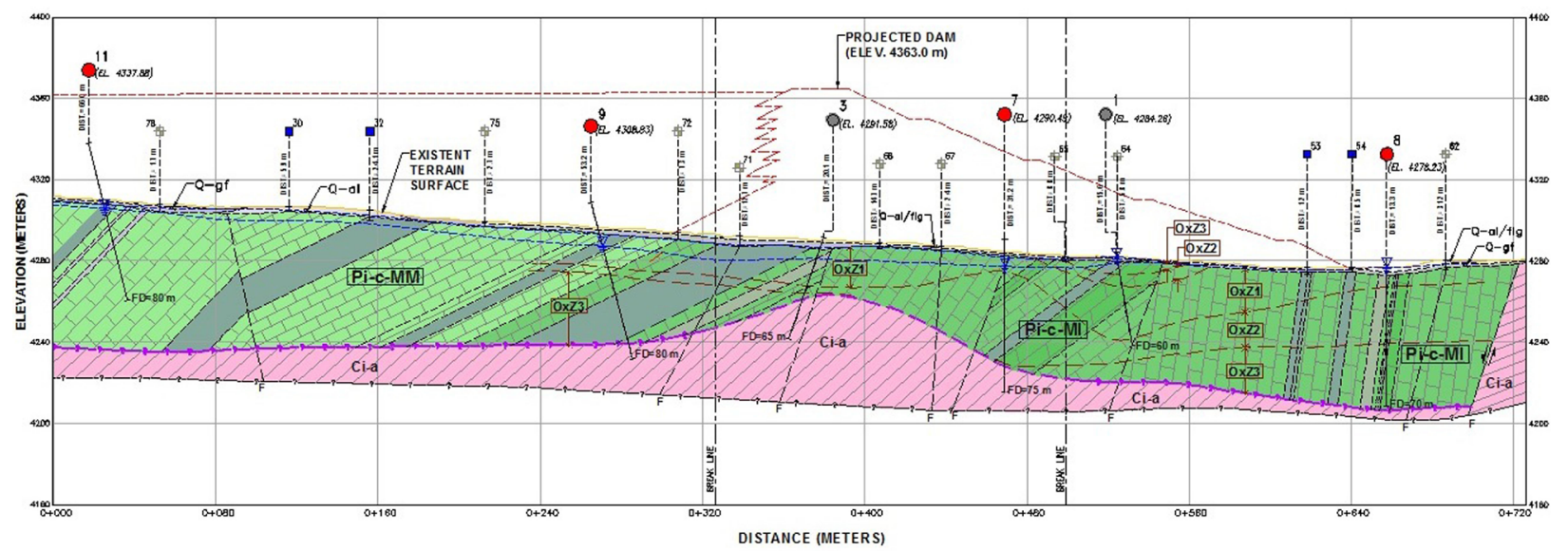

Figure 4. Geological cross section B-B' along the river axis (looking the north valley slope).

Also, anticlines and synclines are present in the area, affecting the Copacabana and Ambo Groups, as shown in Figures 1 and 3; their axes have generally N-S and $\mathrm{E}-\mathrm{W}$ orientations. Bedding orientation of the geological units will be detailed in a following section of this paper.

\section{Geotechnical Boreholes}

Eighteen geotechnical boreholes (4 with directionally oriented core, 4 inclined, and 10 vertical) were drilled along the dam axis and in the TSF impoundment area. Assessment of karstification in the Copacabana Group is based on information from 13 boreholes in which Copacabana limestones were identified. The depth of these boreholes ranges between $40 \mathrm{~m}$ and $140 \mathrm{~m}$.

Permeability tests (Lefranc and Lugeon) were executed in each of the boreholes in order to estimate the hydraulic conductivity of the geologic formations. Additionally, ground water levels in the area were measured in single and double piezometers (Casagrande type) installed in each borehole.

\section{Test Pits and Trenches}

A total of 80 test pits and 3 trenches, with depths varying between 0.8 and $5 \mathrm{~m}$, were excavated to characterize foundation materials and to locate possible sinkholes and cavities. No sinkholes, cavities, or other dissolution features were found in any of the exploratory excavations.

\section{Hydrogeological Studies and Tests}

The hydrogeological studies done in the TSF area were performed by other consultants and their principal objectives were to verify the extent of the Copacabana Group and the degree of karstification. Also, they were intended to determine if there were any significant changes in the flow of the principal stream through the project area and in nearby drainages that could evidence preferential paths of infiltration or discharge of ground waters.

The studies and tests executed in the area consisted of: hydrological and hydrogeological mapping, flow 
measurements of surface waters, pumping tests, slug tests, water levels measured in piezometers, hydrochemical sampling of surface and underground waters, and tracer tests (Fluorescein, Eosin, and Rhodamine) from two injection points in the Copacabana Group, one in the impoundment area, and the other at the north extreme of the dam axis (Figure 1). The tracers were monitored by 30 control points downstream of the injection points; that included some of the installed piezometers, springs, and surface water flows inside and outside the project area.

From the pumping and tracer tests, we found hydraulic connectivity between both banks of the principal stream valley along principal geological structures (faults) present in the area. These faults act as preferential paths for water circulation.

\section{Laboratory Tests}

In order to determine the purity of the carbonate rocks of the Copacabana Group from petrographic and mineralogical viewpoints, we performed 45 petrographic analyses and XRD tests in samples taken from boreholes and outcrops. The results of these analyses provide additional information necessary to assess the karstification degree in the Copacabana Group. Of the 45 total tests, 13 presented calcite as the predominant mineral, 18 presented dolomite, and 14 presented quartz and others minerals associated with siltstones and sandstones. A summary of the results are shown in Table 1.

From these results, we conclude that the Copacabana Group has a varied composition; the lower member presents predominantly calcite and dolomite, while the middle member presents predominantly dolomite, calcite, and quartz.

The high dolomite content reduces the dissolution potential, therefore, the probability of developing significant karstification is generally low (Ford \& Williams, 2007) in the middle member, where the dam will be founded; however, there are some horizons with high content of calcite, which are related to superficial dissolution, that must be treated with appropriate engineering measures. Limestones from the lower member that might be present in part of the dam foundation must be treated as well.

\begin{tabular}{|l|c|c|c|c|}
\hline \multirow{2}{*}{$\begin{array}{l}\text { Copacabana } \\
\text { Member }\end{array}$} & \multirow{2}{*}{$\begin{array}{c}\text { Total } \\
\text { sample } \\
\text { tested }\end{array}$} & $\begin{array}{c}\text { Calcite } \\
(\%)\end{array}$ & $\begin{array}{c}\text { Dolomite } \\
(\%)\end{array}$ & $\begin{array}{c}\text { Quartz } \\
(\%)\end{array}$ \\
\cline { 3 - 5 } & 11 & $9-65$ & $9-97$ & $1-39$ \\
\hline Lower & 34 & $\begin{array}{c}0-64 \\
83-97 *\end{array}$ & $0-97$ & $1-78$ \\
\hline Middle & 34 & & & \\
\hline
\end{tabular}

1. Own elaboration

2. *Presence of some horizons with high content of calcite.

3. The null content of calcite represents siltstones, and sandstones samples.

Table 1. Summary of mineral composition of Copacabana Lower and Middle members.

\section{Assessment of the Factors in Karstification of the Copacabana Group Physiographic Location, Weather, Organic Material Content, and Water $\mathrm{pH}$}

At the beginning of the paper, we noted that the area of the proposed TSF is located on the South Andes of Peru, between 4200 and 4500 m.a.s.l. The weather in the area is cold, with precipitation varying between a dry season (April to November) and a rainy season (December to March). The development of vegetation is limited to ichu (a type of grass typical from the highlands) of low height. The organic soil thickness varies between 0.1 and $0.5 \mathrm{~m}$.

The cold climate of the area, limits the influence of biologic activity and the production of carbonic acid, which is a critical factor in limestone dissolution. The hydrochemical characterization carried out in the area verified that the surface and ground waters present a neutral $\mathrm{pH}$, slightly alkaline, which does not favor karst development.

\section{Stratigraphy of the Copacabana Group}

The Copacabana Group, based on geological mapping, boreholes information and laboratory test results, is predominantly a sequence of limestones, dolostones, and dolomitic limestones with interbedded calcareous sandstones and pelitic rocks (siltstone and shales), in varying proportions. For this reason, this Group has been divided into 3 units (lower, middle, and upper member).

\section{Lower Member}

This unit outcrops mostly at the bottom of the dam area. It consists of limestones and dolomitic limestones 
alternating with horizons of siltstones and dolostones. In two boreholes we identified two cavity zones (lengths between 0.6 and $1.45 \mathrm{~m}$ ). The outcrop area is characterized by the presence of karst towers, defined as isolated, steepsided limestone outcrops separated by topographically low areas, produced by the differential erosion, tectonism and dissolution of the limestones (Maslyn, 1977).

The karst towers are present downstream of the dam footprint, oriented along an E-W alignment, associated with steeply-dipping limestones (Figure 5). They are the result of the structurally controlled solution activity along discontinuities in the rock mass (bedding planes and joints provide access to water). Outside of the dam area, small caves and cavities ( 0.6 to $2.4 \mathrm{~m}$ in diameter) have been identified on the slopes above the area of welldeveloped karst towers. Collectively the karst towers and larger cave and cavities are representative of endokarst.

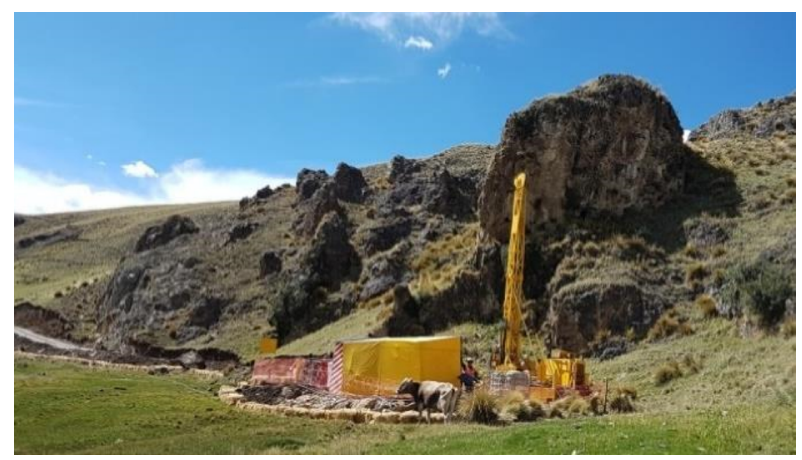

Figure 5. Photo looking NW. Karst towers in the lower member of the Copacabana Group, downstream of the dam footprint.

\section{Middle Member}

This unit outcrops in the north side of the impoundment area and proposed dam footprint. It consists of limestones and dolostones alternating with siltstones and calcareous sandstones.

On the left abutment of the dam (looking downstream), an anticline is present with an $\mathrm{E}-\mathrm{W}$ orientation that is transverse to the dam axis (Figure 6). This zone contains steeply-dipping and jointed rock, which is moderately to highly permeable and requires appropriate engineering treatment before the construction of the dam.

Three isolated dissolution cavities (lengths between 0.3 and $2.25 \mathrm{~m}$ ), partly controlled by the regional fracture system, were identified in three boreholes. These cavities are considered to be isolated epikarst.

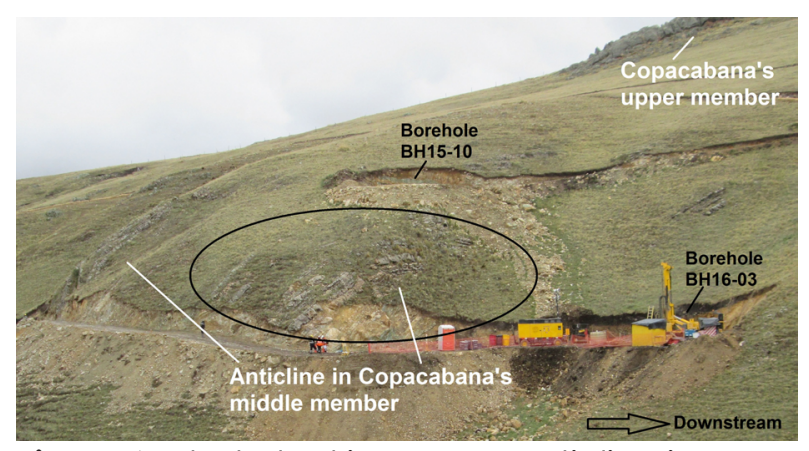

Figure 6. Photo looking NNW. Anticline in middle member at the dam area.

\section{Upper Member}

This unit is present on the north side of the impoundment area and $100 \mathrm{~m}$ above the north side of the axis dam. It extends to the east outside the study area (Figure 7), and consists mostly of quartz sandstones alternating with bituminous siltstone and isolated horizons of limestone. No evidence of karst dissolution is present in the upper member.

\section{Structural Arrangement}

The most important structures identified in the area correspond to geologic faults across the projected impoundment area and dam foundation. These faults strike NW and are filled with mostly clayey sand and gravel-sized material with an average hydraulic conductivity of $6.1 \times 10^{-04} \mathrm{~cm} / \mathrm{s}$, with higher values occurring in the first $30 \mathrm{~m}$ of depth.

Bedrock in the Copacabana's middle and lower members is folded into a relatively tight anticline with steeply-dipping limbs, especially on the north slope above the valley floor.

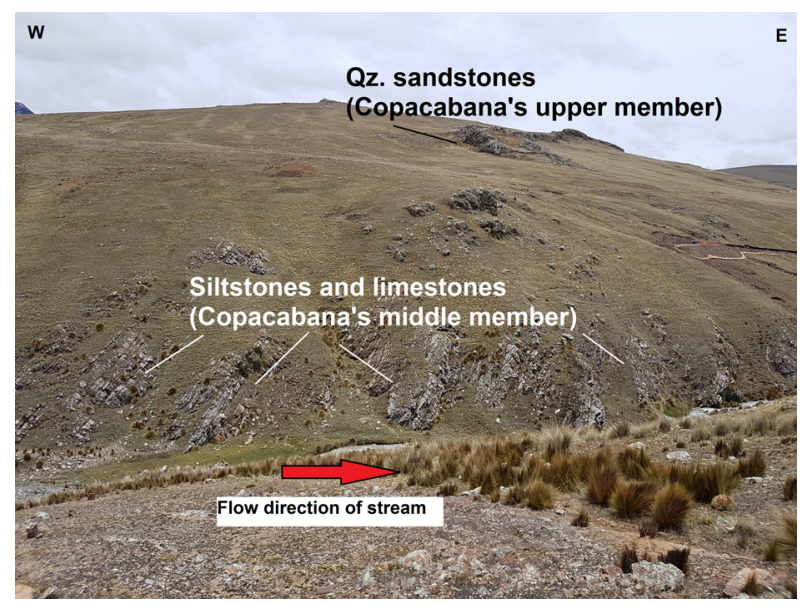

Figure 7. Bedding of the middle member at the impoundment area and quartz sandstone outcrop of the upper member at the top. 
The sub-vertical dips in limestone, coupled with flexural slippage along bedding planes and jointing due to folding, create a favorable environment for solution activity in the limestones (karst towers area).

The bedding of the Copacabana Group on the left abutment of the dam, strikes NW and dips between $20^{\circ}$ to $80^{\circ}$ to $\mathrm{NE}$ or $\mathrm{SW}$, depending of its location regarding the anticline. At the bottom of the projected dam, the Copacabana Group exhibits an E-W to NW strike, with sub-vertical dip to the south. On the right abutment of the dam, the bedding of the Ambo Group strikes almost E-W to NW and dip between $5^{\circ}$ to $65^{\circ}$ to the SW.

The bedding on the impoundment area strikes N-S and dips to the west (Figure 7). This condition is favorable for the watertightness of the TSF, considering that the flow direction of the valley is west to east, and permeability across bedding is lower than along bedding.

\section{Hydraulic Conductivity}

D. Evans establishes a limit for developing karst morphology based on the hydraulic conductivity of limestones from Peru (Evans, 2015) using a depth vs hydraulic conductivity graphic. This limit was applied to the Copacabana's lower and middle member results of 275 permeability tests (Lugeon and Lefranc) executed in the geotechnical boreholes.

The results showed that the middle member would behave as a poor aquifer with hydraulic conductivities between $1 \times 10^{-4} \mathrm{~cm} / \mathrm{s}$ and $1 \times 10^{-6} \mathrm{~cm} / \mathrm{s}$. On the other hand, the lower member, due to its higher alteration degree,

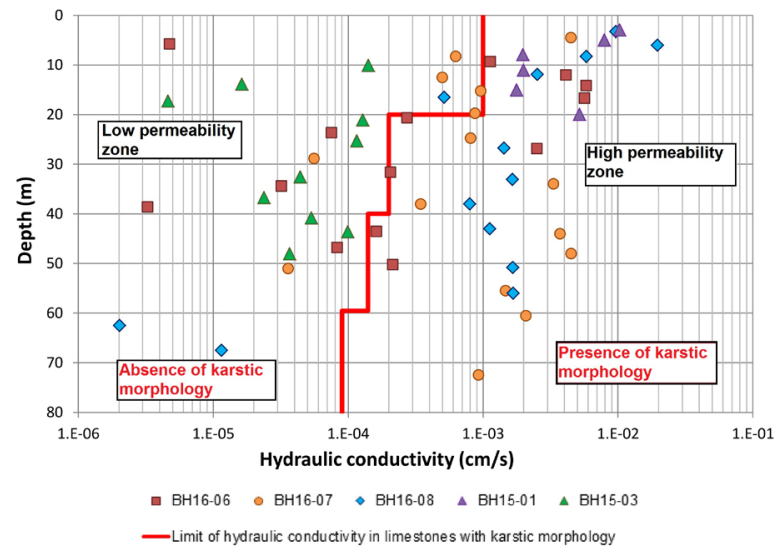

it would behave as a free aquifer semi-confined with a hydraulic conductivity average of $1 \times 10^{-4} \mathrm{~cm} / \mathrm{s}$.

Figure 8 shows that the lower member mostly presents high permeability values, and this analysis indicates that is related to the development of karstic features.

Figure 9 shows the results of the middle member, which presents lower permeability values and therefore a less probability for developing karstic features, except for the results near the anticline zone, which presents high permeability due to the structural alteration of the zone and is related to the cavities found in some boreholes.

\section{Water Levels and Water Circulation}

In the TSF area there are two water levels. The first corresponds to a free aquifer located approximately subparallel to the existing natural terrain, which converges on both sides to the riverbed in the stream valley. The second corresponds to a deep confined aquifer located sub-horizontal at approximately $22 \mathrm{~m}$ in depth. However, downstream of the dam, both levels join at the same elevation indicating that the aquifers are connected and discharge over the rocks of the lower member of the Copacabana Group.

Initially we considered that preferential paths of water circulation could exist, favoring karstic cavities observed in some of the boreholes of the north side of the TSF; however, the results of the tracer tests show shorter paths of local water circulation, limited to the superficial zone of the limestones downstream of the projected dam. In any case, there are not likely to be longer preferential

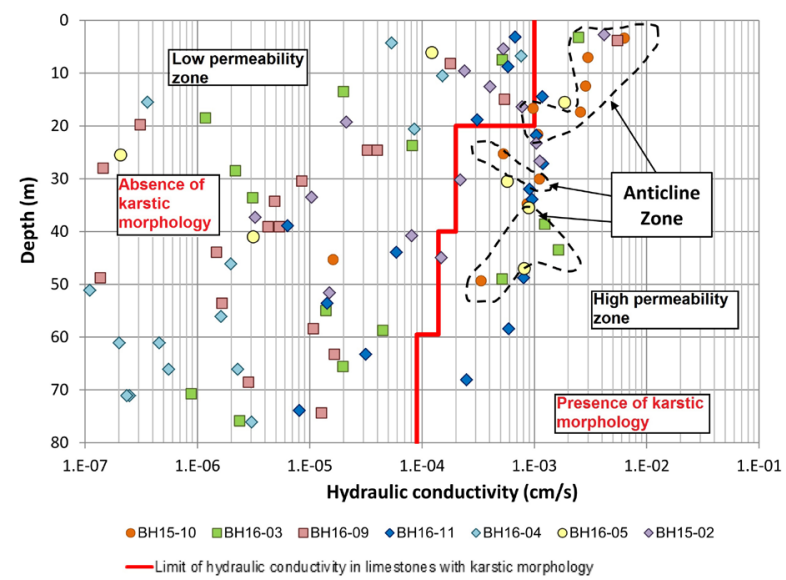

Figures 8 and 9. Hydraulic conductivity values from permeability tests in boreholes (BH 16-XX/BH 15-XX), lower member of the Copacabana Group (left) and the middle member (right). Limit of karstic morphology (red line) from D. Evans, 2015. 
paths because there is no observed remote discharge of water, and the extension of the Copacabana Group is limited. The circulation of water in this area is related mostly to structural features that act as preferential flow paths.

\section{Dissolution and Oxidation Degree}

In the lower member of the Copacabana Group, the degree of dissolution and oxidation observed on the cores is variable. Some sectors exhibit dissolution with high to moderate oxidation up to a depth of $40 \mathrm{~m}$.

The dissolution degree and oxidation observed in the middle member is variable. Some sectors exhibit dissolution with moderate to high oxidation and others are low to null. At depths between 25 to $60 \mathrm{~m}$, evidence of oxidation and dissolution disappears. The shallower depth that shows evidence of dissolution is related to the anticline located on the left side of the dam axis (looking downstream).

In two boreholes drilled in the lower member, we found two cavity zones, with a total length of voids of $2.05 \mathrm{~m}$, representing $0.84 \%$ of the total length $(245 \mathrm{~m})$ drilled in this member. In the middle member, we identified three cavity zones, with a total length of voids of $3.55 \mathrm{~m}$, representing $0.61 \%$ of the total length $(579 \mathrm{~m})$ drilled in the middle member. The finding of voids in five of the boreholes at the site is significant; however, the number of borings in which karst was found is less important than the size of the voids found and the length of voids as percentage with respect to the total number of meters drilled.

We concluded that karst voids are more prevalent in the Copacabana's lower member than in the middle member, which is similar to interpretations from surface geomorphology and geologic mapping.

\section{Human Activity}

Because water $\mathrm{pH}$ is one of the factors that causes dissolution of limestones, we recommend constant monitoring of $\mathrm{pH}$ in the proposed TSF, to prevent any decrease of the $\mathrm{pH}$ below 5 . Decreasing $\mathrm{pH}$ will generate acidic water, and could increase the risk of developing dissolution in the carbonate rocks.

\section{Engineering Measures to Mitigate Risk Due to the Karstification Degree of the Copacabana Group}

According to the recommended treatments described by Schaefer (2009) and Fell (2008), on the projected area of the dam and the TSF, the engineering measures that should be taken includes excavation of weathered, weak rock and/or rock showing evidence of solution activity in the dam foundation, followed by the treatment of joints or cavities with slush grouting or dental concrete depending on the size of the cavities, cracks, or joints discovered.

Also, it will be necessary to construct a grout curtain below the dam core, to fill possible cavities and improve the hydraulic containment of the geologic units. This curtain must reach its greatest depth on the left side of the dam (up to $40 \mathrm{~m}$ ), where the Copacabana Group is present. Cross section A-A' (Figure 4) shows the estimated depth of the grout curtain.

\section{Conclusions}

The karstification degree on the Copacabana Group is variable and depends on the stratigraphy, lithology, mineralogy and geologic structure predominant in the project area. The Copacabana Group is not homogeneous, including solution-prone limestones, and significant quantities of dolostones, siltstones, and sandstones, which are not susceptible to dissolution. With respect to dolostones, dissolution can be very slow and as a consequence, the possibility of developing karst features is low to moderate.

The Copacabana's lower member is characterized by the presence of karst towers and small caves, indicating that this area should be classified as endokarst. The middle member exhibits karst features limited in extent and depth, represented by the isolated cavities found in some boreholes and are considered to be epikarst. Finally, the upper member does not exhibit any evidence of karstic dissolution.

Because of the higher degree of karstification in the lower member, it represents the largest risk to the project. The location of the dam has been designed, as much as possible, to avoid the lower member of the Copacabana Group (karst towers area is outside the footprint of the dam).

After the assessment of the factors relating to the development of karst conditions at the proposed dam and impoundment site, we conclude that the Copacabana Group represents a moderate to low risk to the project. It will be necessary, however, to apply engineering treatments to the foundation before construction of the dam. 


\section{References}

Evans D. 2015. Hydrogeological risks of mining in mountainous karstic terrain: lessons learned in the Peruvian Andes. In Andreo B et al. editors. Hydrogeological and environmental investigations in karst systems. Environmental Earth Scinces 1: 465-475.

Fell R, Foster M, Cyganiewicz J, Sills G, Vroman N, Davidson R. 2008. "Risk analysis for dam safety - A unified method for estimating probabilities of failure of embankment dams by internal erosion and piping - Guidance document". Bureau of Reclamation, US Army Corps of Engineers, UNSW, URS Australia. North Sydney. p. 4-4-4-5, 8-15-8-26.

Ford D, Williams P. 2007. Karst Hydrogeology and Geomorphology. West Sussex, England: John Wiley \& Sons Ltd. p. 28-36.

Lopez J, León W; De la Cruz W. 1996. Geología del Cuadrángulo de Macusani, 29-v, Boletín A 079, INGEMMET, p. 37-56, 75-76.

Maslyn RM. 1977. Fossil Tower Karst Near Molas Lake Colorado. The Mountain Geologist, Rocky Mountain Association of Geologists, Denver, CO, 14 (1): 17-25.

Schaefer J. 2009. Risk Evaluation of Dams on Karst Foundations. In: U.S. Society of Dams editors. Managing Our Water Retention System, 29th Annual USSD Conference, USSD; 2009 April 20-24; Nashville, Tennessee. p. 541-579.

Waltham T, Bell F, Culshaw M. 2010. Sinkholes and subsidence, karst and cavernous rocks in engineering and construction. 
